\title{
Do dividends announcements signal future earnings changes for Jordanian firms?
}

\author{
Wasim Khalil Al-shattarat, Gulf University for Science and Technology \\ Basiem Khalil Al-shattarat, Prince Sultan University, Riyadh, Saudi Arabia \\ Ruba Hamed, University of Portsmouth, Portsmouth, UK
}

\begin{abstract}
Purpose. This study examines the signalling hypothesis of dividends by testing empirically the market reaction to dividends announcements. Furthermore, this study examines the information content of dividends announcements with respect to future earnings changes for a sample of Jordanian industrial firms over the period 2009 to 2015.

Design/methodology/approach. The authors mainly used the event study methodology (ESM) to examine the market reaction to dividend release announcements. The market model is used to generate the expected returns. Also, the $t$-test is used to examine the significance of the mean and cumulative abnormal return. Furthermore, a simultaneous-equation model developed by Nissim and Ziv (2001) and Grullon et al. (2005), applying the two-stage least squares (2SLS), is used to examine the relationship between dividends changes and future earnings changes.
\end{abstract}

Findings. The results reveal consistency with the limited extant empirical evidence for developing markets and provide some new insights for Jordanian listed firms that support the signalling hypothesis. In applying the event study methodology, the information content of dividends shows that there is a significant positive market reaction to dividends announcements. The findings also present a strong relationship between dividends announcements and profitability in the year of announcements and the subsequent year, whereas this relationship does not exist in the second year. Our findings show that there is value-relevance for dividends, suggest that investors recognize the signalling purpose and discern that dividends announcements are useful in predicting favourable and unfavourable future earnings in the short run (the same year and subsequent year), and show also managers may use dividends to signal earnings prospects in anticipation of expected future market benefits.

Originality/value. This paper contributes to the literature by providing a workable test for the dividend signalling hypothesis, applying a simultaneous-equation model that incorporates the market reaction to dividends announcements and future earnings changes. Moreover, this paper uses a recent data set of dividends announcements in Jordan. This study provides additional insight to support the signalling hypothesis in emerging markets. Overall, current and previous studies have focused typically on investigating dividend policy in developed markets, especially the US and European markets, whereas there has been limited analysis of dividends changes on earnings changes for developing markets.

Practical Implications. The support of the signalling effect implies the existence of information symmetries, at least theoretically, between management and investors. These findings could have implications for Jordan's existing corporate governance practices and firms' disclosure environment.

Keywords Earnings, Dividends, Jordan

Paper type Research paper 


\section{Introduction}

Managers' perceptions of dividend policy and dividends' empirical characteristics have been examined extensively for developed markets (Baker et al., 2002; Brav et al., 2005). In contrast, there has been limited investigation of dividend policies for firms listed on developing markets (Abdulla, 1992; Aivazian et al., 2003). It is important for investors in any market to understand the factors that motivate managers to pay dividends and identify their key drivers. In the context of developing markets, how and why firms return value to investors is important from an economic development perspective. Establishing capital markets and maintaining investor confidence are integral elements of most developing economies' economic policies. The ability to transfer surplus funds to productive investment opportunities is vital to promote economic growth.

The signalling theory of dividends contends that dividends serve as a prospective signalling device because managers own asymmetric information about firms' future profitability. Therefore, the relationship between dividend changes and future profitability becomes an important empirical issue in corporate finance. In the literature, two methods are generally used to test the hypothesis. The first method examines whether dividend changes can predict subsequent stock price changes; the second examines whether dividend changes can predict subsequent accounting earnings changes. Under both methods, the signalling hypothesis is tested by looking at the predictive ability of dividend changes. Specifically, under these methodologies, if the predictive ability of dividend changes is statistically confirmed, it is inferred that the signalling hypothesis is valid, meaning that firms use dividend changes to signal their future profitability. One of the advantages for testing the dividend signalling hypothesis is to examine the mutual relationship between dividend changes and future earnings changes. Furthermore, because managers' expectations of future profitability can influence dividends, dividend changes can thereby influence future profitability by affecting the capital structure of the firms.

This means that a stronger econometric methodology that accounts for this endogenous relationship between dividend changes and future profitability is needed to more accurately test the dividend signalling theory. Therefore, the first motivation for this work is to attempt to address this endogeneity problem by examining the relationship between dividend changes and future earnings changes using a simultaneous equation method. Second, while there is a significant body of empirical evidence for developed economies, there has been relatively limited investigation into the informational content of dividends change announcements regarding a firm's improved future profitability in developing economies. Given the dearth of empirical evidence for firms listed on the Jordanian stock market, the aim of this study is to ameliorate this situation by investigating the signalling hypothesis of dividends and their impact on future profitability data sets of Jordanian industrial firms. Therefore, we test the market reaction to dividend announcements following the signalling hypothesis proposed in the literature to explain dividends' behaviour. The dividend signalling theory postulates that dividends convey information about current and future levels of earnings to the market. Consequently, a positive relationship exists between the market reaction and future profitability.

Thus far, many of the empirical findings on the impact of the profitability factor on dividend behaviour have been inconclusive and have mainly concentrated on developed countries such as the USA and the UK. Even though evidence from emerging markets has been limited, a few attempts have been made to study the determinants of dividend policy, such as Adelegan (2003) in Nigeria; Ayub (2005), Ahmed and Attiya (2009), and Afza and Mirza (2010) in Pakistan; Al-Yahyaee et al. (2006) in Oman; and Omet (2004) and Al-Najjar (2009) in Jordan. However, these studies did not cover the impact of information content on future profitability, which many researchers contend is a potential determinant of dividend policy. Al-Najjar (2009) indicated that dividend policy in Jordan is influenced by factors similar to those in developed countries. 
This paper contributes to the literature by providing a workable test for the dividend signalling hypothesis, applying the event study methodology (ESM). A simultaneous-equation model incorporates the market reaction to dividends announcements and future earnings changes, where the future earnings change equation is the regression of future earnings changes on dividends announcements. The incorporation of the two variables addresses the mutually endogenous problem. This means that if a univariate equation is estimated using the ordinary least squares (OLS) method, the results can be biased and inconsistent and then lead to an erroneous inference. In this study, we follow the work of Nissim and Ziv (2001) and Grullon et al. (2005) in addressing this statistical problem. The equation model is estimated by applying the method of two-stage least squares (2SLS). Additionally, this paper uses a more recent data set of dividend announcements in Jordan than has been employed in other studies. This study may provide additional insight to support the signalling hypothesis in emerging markets. Overall, current and previous studies have typically focused on investigating dividend policy in developed markets, particularly the US and European markets. To date, there has been limited analysis of the determinants of dividends changes for Jordanian firms. El-Khouri and Almwalla (1997) tested the signalling hypothesis by employing the event study methodology to examine the information content of dividend changes. They reported no significant price impact for dividend increases or decreases. In contrast, Omet and Abu-Ruman (2003) adopted the survey approach and reported that managers viewed dividends as a signalling device. While the results of the signalling hypothesis for Jordanian firms are mixed, this study contributes to the literature in a number of ways. To begin with, the first aim of this study is to investigate the market reaction to dividend release announcements for Jordanian listed firms. We examine actual dividend payments, and extend the extant Jordanian literature by investigating the extent to which signalling theory explains future profitability. Hence, this paper will contribute to the literature of dividend policy in developing markets by investigating the impact of dividend policy on future profitability using the Jordanian data set.

Our empirical analysis supports the signalling hypothesis. The information content of dividends, in our application of the ESM methodology, shows that there is a significant positive market reaction to dividends announcements. The findings also present a strong relationship between dividends announcements and firm profitability in the year of announcements and the subsequent year, whereas this relationship does not exist in the second year following announcements. Our findings show that there is value relevance for dividends, thus supporting the signalling hypothesis in the short run. Moreover, our findings suggest that investors recognise the signalling purpose and show that dividends announcements are useful in predicting the favourable and unfavourable future earnings in the short run (the same year and the subsequent year). Also, managers may use dividends to signal the earnings prospects of their firms in anticipation of expected future market benefits. As for the test of the predictive ability of dividend changes on return on assets (ROA) changes, we found a significant positive relationship between dividend changes and ROA changes in year 1. But for year 2, our models report an insignificant relationship between dividend changes and ROA changes. The results are the same when applying a nonlinear model. The results indicate that an increase in dividends, for example, predicts a forthcoming increase in ROA. The more the dividend increases, the more the ROA increases. Because the change in dividends had been shown to be for the purpose of signalling ROA changes, it is beneficial to the firm's future ROA because it increases the funds available for potential investment opportunities that are not subject to the capital structure of firms. Overall, our findings are consistent with the limited extant empirical evidence for developing markets and provide some new insights for Jordanian listed firms.

A cornerstone of economic policy in many developing economies involves financial sector reform which includes developing capital markets. The underpinning rationale is that well-developed capital markets attract international investors, mobilise domestic savings, and provide liquidity, which promotes economic growth. Apart from being a source of return to equity investors, firms' ability to pay dividends promotes confidence for capital markets and investors. Consequently, it is important to investors and economic policy makers alike to understand the dividend policy behaviour of firms. Moreover, the support of a signalling effect implies an existence of information symmetry, at least theoretically, between management and 
investors. On the other side, this study could not reflect the levels of inside ownership or the existence of signalling substitutes. Despite this, these findings could have implications for Jordan's existing corporate governance practices and firms' disclosure environment.

The rest of this paper is organised as follows. The second section reviews the literature for developed and emerging markets and identifies the gap in the literature from a Jordanian perspective. The third section presents background on the Jordanian market. The fourth section outlines the research design, which includes the sample selection, our model, and the methodology. The fifth and sixth sections report and discuss our empirical results, while the last section concludes our paper.

\section{Literature}

Miller and Modigliani (1961) demonstrated that the market value of a firm has no reliance on its dividend policy within a perfect stock market. They postulated that the firm's earnings and investment only affect the market value and that dividend policy has nothing to do with its market value. This is called the dividend irrelevance hypothesis. Since Miller and Modigliani's theory, many researchers have tried to explain that dividend does matter, and have tried to link it with the value of the firm. These endeavours to explain dividend policy have employed different theories, such as bird-in-the-hand theory, agency cost theory, tax clientele theory, and signalling theory. These theories were attempts to clarify the behaviour of dividend policy determined by corporate managers. Miller and Modigliani's theory was based on the perfect market, while with imperfect markets, dividends matter.

Theoretically, one of the most important issues in corporate finance is whether dividend changes contain information about future earnings and profitability. Although dividend signalling theories imply that dividend increases signal better prospects (e.g., Bhattacharya, 1979; John \& Williams, 1985; Miller \& Rock, 1985), many empirical studies have failed to support this idea. Studies by Watts (1973), Gonedes (1978), Penman (1983), DeAngelo et al. (1996), Benartzi et al. (1997), and Grullon et al. (2002) have found little or no evidence that dividend changes predict abnormal increases in earnings. Similarly, evidence based on surveying and interviewing hundreds of financial executives indicates that managers reject the notion that dividends are used as a cost signalling device (Brav et al., 2005).

The signalling theory of dividends argues that dividends serve as a prospective signalling device because managers own asymmetric information about firms' future profitability. Therefore, the relationship between dividend changes and future profitability becomes an important empirical issue in corporate finance. In the literature, two methods are usually used to test the hypothesis. The first method examines whether dividend changes can predict subsequent stock price changes. The other examines whether dividend changes can predict subsequent accounting earnings changes. Under both methods, the signalling hypothesis is tested by looking at the predictive ability of dividend changes. Specifically, under these methodologies, if the predictive ability of dividend changes is statistically confirmed, it is inferred that the signalling hypothesis is valid, meaning that firms use dividend changes to signal future profitability. One of the objectives of this paper is to provide a workable test for the dividend signalling hypothesis with a more accurate model by examining the mutually endogenous problem between dividend changes and future earnings changes. Furthermore, because managers' expectation of future profitability can influence dividends, dividend changes thereby can influence future profitability by affecting the capital structure of the firms. This means that a stronger econometric methodology that accounts for this endogenous relationship between dividend changes and future profitability, and controls for other motives, is needed to more accurately test the dividend signalling theory. This paper attempts to address this by examining the relationship between dividend changes and future earnings changes using a simultaneous equation method. 
In reviewing the literature, even with the evidence that stock returns positively follow dividend change announcements (e.g., Petit, 1972; Aharony \& Swary, 1980; Asquith \& Mullins, 1983; Bajaj \& Vijh, 1990; Kalay \& Loewenstein, 1985), whether managers indeed change the dividends to signal the earnings prospects of their firms cannot be completely discerned by the existing test methodology. The possibility exists that investors may rationally or irrationally conclude that dividend changes are always used by managers as a signalling device. This causes them to positively (negatively) react to the dividend increases (decreases) but without contemplating that in addition to signalling, managers may change dividends for other reasons. Moreover, Watts (1973), Gonedes (1978), Penman (1983), DeAngelo et al. (1996), Benartzi et al. (1997), Nissim and Ziv (2001), Grullon et al. (2002), Brav et al. (2005), Grullon et al. (2005), Denis and Osobov (2008), Braggion and Moore (2011), et al. directly examined whether dividend changes can predict subsequent accounting earnings changes instead of future stock returns. However, their results still cannot completely discern whether the relationship between dividend changes and subsequent earnings changes is due to signalling because managers may change dividends, for example, to retain more capital for future investments or to disburse excess cash for which they have no better alternative short-term use. In short, no matter what the motives are, the distribution of dividends itself may have an impact on future earnings. According to Myers and Majluf (1984), internal finance for projects is preferable to external finance because of its lower costs and less resistance. With regard to dividend changes, because dividend increases reduce the funds available for investment, firms may either lose potential positive net present value projects or have to finance the projects with higher costs. Either may result in a decline in future earnings. Alternatively, the well-known constant dividend growth model (Gordon, 1962) shows that with constant expected return of portfolios, high dividend payouts should be offset by low expected earnings growth. In contrast, agency theory (Jensen, 1986, 1988; Jensen \& Meckling, 1976) yields different predictions. Since managers could allocate resources to activities that benefit themselves or invest in negative net present value projects, the increased payouts can reduce potential agency costs. Meanwhile, dividend payouts also bring firms under greater monitoring of capital markets because the firms will visit the capital markets more frequently for financing needs. Both situations will be beneficial to the firm's future earnings. Therefore, there is no unique impact of dividend changes on future earnings.

Empirically, investigation of dividends has generally followed two streams. One strategy has been to adopt the econometric approach to test the theories that have been proposed in the literature. As an alternative, surveys of managers' views have sought to determine what decision makers believe to be the key determinants of dividend policy (Abdulla, 1992; Baker et al., 2002; Brav et al., 2005). The empirical literature examining many facets of dividend payments suggests that the dividend policy decision is complex and cannot be characterised by a single theory. In an asymmetric information environment, dividend initiations and changes have the potential to convey management's private information to outsiders (Bhattacharya, 1979; John \& Williams, 1985; Miller \& Rock, 1985). The signalling hypothesis has been tested extensively across a range of developed markets. The resulting empirical evidence shows that security prices react positively to dividend increases and negatively to dividend decreases (Aharony et al., 1988; Borde et al., 1999; Eades et al., 1985; Impson, 1997). In terms of dividend initiations and omissions, the evidence indicates that the market reacts favourably to dividend initiations and vice versa (McCaffrey \& Hamill 2000; Michaely et al., 1995).

Extending the review of the empirical literature to assess whether dividend changes contain information about the future earnings of the firm, the results from studies that examined the relationship between dividend changes and future earnings are mixed. Watts (1973), Gonedes (1978), Penman (1983), DeAngelo et al. (1996), Benartzi et al. (1997), Nissim and Ziv (2001), Grullon et al. (2002), Brav et al. (2005), Grullon et al. (2005), Denis and Osobov (2008), Braggion and Moore (2011), Chen and Kao (2014), Liu and Chen (2015), and Huang et al. (2017), among others, directly examined whether dividend changes can predict subsequent accounting earnings changes instead of future stock returns. However, their results still cannot completely discern whether the relationship between dividend changes and subsequent earnings changes is 
due to signalling because managers may change dividends, for example, to retain more capital for future investments or disburse excess cash for which they have no better alternative short-term use.

In short, motives aside, the distribution of dividends itself may have an impact on future earnings. Healy and Palepu (1988) showed that firms that initiate (omit) dividends realise a significant increase (decrease) in their annual earnings for at least one year before and the year of dividend change. Similarly, these firms have significant increases and decreases in earnings for at least one year after the announcement. In the case of initiating firms, earnings increase for two years following these dividend increases. DeAngelo et al. (1996) showed that dividend increases are not informative signals about future earnings and that some firms' favourable dividend actions could likely be managerial mistakes. Benartzi et al. (1997) found a very strong lagged and contemporaneous correlation between dividend changes and earnings. But in the two years following the dividend increase, they found that earnings changes are essentially unrelated to the sign and the magnitude of the dividend change.

Contrary to the evidence above, Nissim and Ziv (2001) posited that studies like that of Benartzi et al. (1997) are misspecified due to the "measurement error" in the dependent variable and the "omitted correlated variable" problem. They argued that both measurement errors and model misspecifications might account for adverse effects of dividend signal hypotheses. First, they observed that most studies falsely use the previous market value of equity, which can reflect future earnings too early, as a deflator of subsequent earning changes, and instead employ the previous book value of common stocks in their empirical analysis. Second, as reported in the literature, they defined return on equity (ROE) as a key predictor for earning changes. In particular, the mean reversion of ROE implies decreased future earnings when the current ROE level is higher than its long-term average, and vice versa. Moreover, Nissim and Ziv (2001) assumed that current earnings follow the data generating mechanism of first-order autocorrelation. Accordingly, they specified current ROE as a proxy for omitted correlated variables for future profitability and found robust evidence for the dividend signal hypothesis regardless of the dependent variable of future earning changes, future earnings, or future abnormal earnings. After addressing these problems, they found that dividend changes are positively associated with earnings changes in each of the two years following the dividend changes. Nissim and Ziv considered a particular model of earnings expectations and found a positive association between current dividend changes and future earnings changes. They argued that previous studies failed to uncover the true relationship between dividends and future earnings because researchers used the wrong model to control for the expected changes in earnings. Specifically, they reported that, when using a regression analysis that controls for a particular (linear) form of mean reversion in earnings, dividend changes are positively correlated with future earnings changes. Their findings are surprising, because past researchers who have used control variables in a regression context have found the opposite relationship (Penman, 1983), no relationship, or a very weak relationship (Benartzi et al., 1997).

Following similar logic, Harada and Nguyen (2005) presented another argument that the diversity of motivations adopted by managers in dividend adjustments makes the actual dividend changes data easily fall into adverse dividend signal hypotheses. Therefore, they believed that expected dividend increases are only informative when corroborative with current profit increases and brighter financial measures; otherwise, they might only represent managers' optimism regarding future prospects. Accordingly, Harada and Nguyen (2005) employed the

logit model to screen a sample of firms with consistent prospects, and discovered the validity of dividend signal hypotheses in terms of expected dividend change models.

Recognising the potential nonlinearities in the relationship between dividends and earnings, many prior investigators have used methods other than regression analysis and found results opposite to the ones in Nissim and Ziv. For example, DeAngelo et al. (1996) analysed dividend policy during times where firms' earnings unexpectedly decline and found that dividend changes contain virtually no information about future changes in earnings. Benartzi et al. (1997) used a matched sample approach, in which dividend- 
changing firms are matched to no-dividend-changing firms based on their attributes such as market capitalisation, industry, and past earnings performance. Controlling for the earnings pattern and mean reversion, they found no evidence of positive abnormal earnings changes after dividend increases. Similar results were obtained by Grullon et al. (2002). In fact, a simple comparison of the evolution of earnings for dividend-changing firms (e.g., Grullon et al., 2002) yields results opposite to those drawn by Nissim and Ziv (2001). These consistent findings across studies and methodologies make the Nissim and Ziv results surprising and important to the question of why firms pay dividends.

Grullon et al. (2005), however, re-examined the results by using a nonlinear model for earnings expectations and found that dividend changes contain no information about the earnings changes. More recently, Lukose and Rao (2010) examined the stock price reaction to dividend changes and the relevance of signalling models in explaining the valuation effects associated with dividend changes for Indian industrial firms. They found a significant wealth effect around dividend changes and profitability during the year of dividend change. Similarly, Liu and Chen (2015) tested the signalling hypothesis of dividends by examining whether managers change dividends to signal their expectation of earnings prospects, using the simultaneous equation approach for US firms. Their results showed that managers change dividends to signal equityscaled rather than asset-scaled earnings prospects. Also, they found evidence that managers change dividends to signal previous earnings change and for catering to dividend clientele.

While the majority of the extant empirical evidence has examined developed markets, there is a dearth of empirical evidence investigating the dividend policies of firms listed on emerging capital markets. From the evidence that does exist, a number of results emerge which call for further investigation. Furthermore, Travlos et al. (2001) examined the market reaction to dividend increase and stock dividends in Cyprus. They elicited a significant positive abnormal return for both events, inferring that special characteristics of the Cyprus stock market delimit applicability of most traditional explanations for cash and stock dividends in favour of an information signalling explanation. In another emerging market, Dasilas (2007) documented a significant market reaction on dividend announcements dates when studying the Athens capital market. His results lend support to the signalling hypothesis.

To date, there has been limited analysis of dividend policies for Jordanian firms. El-Khouri and Almwalla (1997) tested the signalling hypothesis by employing the event study methodology to examine the information content of dividend changes. They reported no significant price impact for dividend increases or decreases. AlShattarat et al. (2012) investigated the market reaction to dividend change announcements for a sample of Jordanian firms. They used the event study methodology (ESM) covering the period 2000 to 2006. Their findings did not support the signalling hypothesis for dividend change, and their suggestion was that markets' prices might react to dividends themselves, rather than to the change in dividends. In contrast, Omet and Abu-Ruman (2003) adopted the survey approach and reported that managers viewed dividends as a signalling device. While the results of the signalling hypothesis for Jordanian firms are mixed, this study contributes to the literature in a number of ways. To begin with, the first aim of this research is to investigate the informational content of dividends announcements for Jordanian listed firms. We examine actual dividend payments, as opposed to managers' views, and extend the extant Jordanian literature by investigating the extent to which dividend payments can explain the future profitability for Jordanian firms.

\section{Background of the Jordanian Market}

The development of the Amman Stock Exchange (ASE) has been at the heart of Jordan's economic development plan. Expansion of the private sector is central to the promotion of growth and expanding wealth opportunities. Emerging economies' policy objectives include encouraging investment, improving productivity, jobs creation, and increasing the standard of living for their citizens. To ensure continued 
economic development, it is crucial that the ASE is considered an optimal vehicle for converting available funds into capital to finance worthwhile investment opportunities. This will only occur if outside investors - in particular those who have a minority interest - are confident that their investments will not be expropriated by insiders/controlling shareholders who have control of the firm's assets.

Similar to many other emerging markets in the region, the Jordanian market is prone to financial constraints and continues to be largely affected by regional uncertainties arising from the previous and recent Gulf crises. These issues and the underdevelopment of the Jordanian bond market (Booth et al., 2001) prompted banks to adopt more conservative credit policies (Zurigat \& Gharaibeh, 2011) and limited the alternative financing options available to firms seeking to finance their new investment opportunities. Consequently, Jordanian firms tend to rely largely on short-term debt financing to reduce the agency cost of asset substitution, as suggested by Jensen and Meckling (1976). Firms in Jordan face institutional problems such as ownership structure, transparency, and investor protection, which cause conflicts of interest, arising from the lack of compatible regulations and sufficient supervision, in addition to complications faced due to bankruptcy, tax laws, capital market liquidity, and lack of competition. Therefore, the presence of such market frictions, information asymmetries, and agency costs restricts Jordanian firms' access to external capital; this is particularly the case for small firms. These firms tend to then follow hierarchical behaviour with respect to sources of finance, which subsequently reduce the payment of dividends. Aivazian et al. (2003) classified the Jordanian market in a "grey zone" that may follow a similar pattern of dividend policy to that in developed markets like the US market. Therefore, this study discusses the case of Jordan specifically, because it shares similarities with other emerging markets. On the other hand, and due to the difference in institutional contexts between an emerging market such as Jordan and developed countries, the empirical association of earnings on dividend changes may differ.

This study analyses the effects of earnings on changes in dividends, spanning a testing period of seven years from 2009 to 2015. Following and expanding on previous studies, the study applies a refined methodology for testing the relationship between dividend changes and future earnings changes, which leads to further improvement on the outcomes of the analysis. Therefore, the study focuses on examining dividend changes in light of future earnings changes that were found to be more significant. Specifically, it provides a more significant indication for dividend changes in larger firms because it overcomes the opportunistic manipulation of managers, and the role of accruals in explaining dividend changes is dependent on these firms' characteristics.

\section{Research Design}

\subsection{Sample Selection}

We analysed a seven-year period from 2009 to 2015 . The sample began with 2009 to remove any effect of the 2008 financial crisis on the analysis. Only industrial firms were analysed, because banking, insurance, and service firms are heavily regulated and their accounting conventions are different from industrial firms (Fukuda, 2000; Impson, 1997; Mullah, 2001). The raw data were collected from the ASE's research department. The firms' reports and the stock market publications were also used in the data collation process.

Firms were eliminated from the sample if any of the following had occurred: (1) any firm that increased its capital by issuing new stocks or distributing dividends as stocks (stock dividend) or decreased its capital because it had financial problems; (2) any firm that was suspended or reintroduced because of reporting problems or financial losses or fall in bankruptcy; and (3) firms that had missing data for the dependent or independent variables during the period of study. Our final sample consisted of 64 firms with 448 observations - 264 observations relating to dividend release announcements and 184 observations related to no-dividends release. Table 1 summarises the number of observations for the final sample. 
Insert Table 1

\subsection{Hypothesis Development}

Most finance theories have accepted Miller and Modigliani's (1961) dividend irrelevance proposition as logical, believing that the level of dividends does not matter in a perfect market. Essentially, they hypothesized that in perfect markets, it does not matter what capital structure a company uses to finance its operations. They theorized that the market value of a firm is determined by its earning power and by the risk of its underlying assets, and that its value is independent of the way it chooses to finance its investments or distribute dividends. If it does matter, then one knew that only market imperfections could be the reason. Information asymmetry is one of the imperfections that might affect dividend policy. Within the information asymmetry proposition, the signalling hypothesis was proposed to interpret the dividend policy. This hypothesis assumes that dividends convey information about earnings and send a message to investors about the firm's future cash flows; thus, it is used as a signal to transmit the private information of the managers to the capital market. Most empirical studies have documented a significant and positive stock market reaction to dividend announcements. Therefore, the purpose of the first part of our analysis is to examine whether the market reacts to the release of dividends, a test of the signalling hypothesis of dividends. Consequently, we hypothesise that a positive market reaction in the ASE is seen following dividend release announcements because increases in dividends will reflect to the market managers' belief about future cash flow. We applied the event study methodology (ESM) to investigate if there is any abnormal return on and around the announcement day. Following are the hypotheses for the mean abnormal return (MAR) and cumulative abnormal return (CAR):

H1a: There is a significant positive MAR when dividends are released, and accordingly a significant positive CAR.

$$
M A R_{\tau}>0 \quad \text { for some } \tau, \quad \text { and } C A R_{m 1, m 2}>0 \quad \text { for } \mathrm{m} 1 \text { to } \mathrm{m} 2
$$

H1b: There is not a significant change in the mean abnormal return when no dividends are released, and accordingly there is not a significant change in the CAR.

$$
M A R_{\tau}=0 \quad \text { for some } \tau, \quad \text { and } C A R_{m 1, m 2}=0 \quad \text { for } \mathrm{m} 1 \text { to } \mathrm{m} 2
$$

Furthermore, the purpose of the second analysis is to examine whether managers release dividends to communicate with investors about firms' future profitability, a retest of the signalling hypothesis of dividends. Because, relative to investors, managers are insiders and own asymmetric information about their firm's performance, managers who predict more favourable (unfavourable) earnings prospects are expected to pay out more (less) dividends to signal this information. Thus, it is hypothesised that current dividend releases are positively related to the forecasted future earnings changes, while no-dividend releases are not related to the forecasted future earnings changes. The hypotheses on the dividend release and no-dividend release are stated as follows:

H2a: The CARs for the dividend releases are associated with future equity-scaled earnings increases.

$\mathrm{H} 2 \mathrm{~b}$ : The CARs for the no-dividend releases are not associated with future equity-scaled earnings increases.

\subsection{Methodology}

\subsubsection{Event Study Methodology}

Event study methodology is a powerful tool that can help researchers assess the financial impact of changes in corporate policy. Using this method, a researcher determines whether there is an "abnormal" stock price effect associated with an unanticipated event. From this determination, the researcher can 
infer the significance of the event. The objective of an event study is to measure whether there are any abnormal or excess returns earned by security holders accompanying special events. These events are, for example, earnings announcements, dividend announcements, merger announcements, stock splits, director's share-holdings and the release of audit reports, etc. Event studies are concerned with the extent to which security returns around the release of the event are "abnormal", which is the difference between observed return and expected return that is calculated by a particular return-generating model. The results of event studies not only can have serious implications in forming accounting or government policy, but also can provide an important source of market information to both individual and institutional investors. Additionally, event studies can be used to study market efficiency on the semi-strong form by analysing the market reactions to these "events" (Peterson, 1989).

The event study methodology has become popular because it obviates the need to analyse accountingbased measures of profit, which have been criticised because they are often not very good indicators of the true performance of firms. For example, managers can manipulate accounting profits because they can select accounting procedures. Stock prices, on the other hand, are not as subject to manipulation by insiders. Stock prices are supposed to reflect the true value of firms, because they are assumed to reflect the discounted value of all future cash flows and incorporate all relevant information. Therefore, event studies, which are based on stock price changes, should measure the financial impact of a change in corporate policy, leadership, or ownership more effectively than a methodology based on accounting returns. Furthermore, the event study method is relatively easy to implement, because the only data necessary are the names of publicly traded firms, event dates, and stock prices.

We employed the event study methodology to examine the signalling hypothesis of dividend announcements. First, this study adopted the general assembly meeting date as an event date, because on that date dividends are approved officially. Second, we used 100 trading daily observations as the estimation period from day $T=-11$ to Time $l=-110$ before the event period, and we employed the event period of 11 trading days, covering the period $T+l=-5$ before to $T+m=+5$ after the announcement. Third, the daily returns were calculated as the natural logarithms of the stock price given by the equation below.

$R_{i, t}=\log _{e}\left(P_{i, t}+D_{i, t}\right)-\log _{e} P_{i, t-1}$,

where

$R_{i, t}$ is the daily stock returns for security $i$ at day $t, P_{i}$ is the natural logarithm of the stock price $i$ at either day $t$ or day $t-1$, and $D_{i, t}$ is the dividend on security $i$ at day $t$.

The returns on the ASE index were computed as the natural logarithm of the first differences of the market index according to the equation below.

$R_{m, t}=\log _{e} I_{t}-\log _{e} I_{t-1}$,

where

$R_{m, t}$ is the market return at day $t$, and $I$ is the natural logarithm price index of the market at either the end of day 1 or day $t-1$.

Then, the market model was used to generate the expected returns as follows:

$\boldsymbol{R}_{i, t}=\alpha+\beta \boldsymbol{R}_{m, t}+\varepsilon_{i, t}$,

where

$R_{i, t}$ is the daily returns of security $i$ at day $t, R_{m, t}$ is the daily returns on ASE index at day $t . \varepsilon_{i, t}$ is the residual (abnormal return) of security $i$ at day $t$, and $\alpha$ and $\beta$ are parameter estimates of the market model. $\beta=\operatorname{cov}\left(R_{i, t}, R_{m, t}\right) / \operatorname{var}\left(R_{m, t}\right)$, and $\alpha=E\left(R_{i, t}\right)-\beta E\left(R_{m, t}\right)$ 
The residual (abnormal returns) $\varepsilon_{i, t}$, therefore, was calculated from the following equation:

$\varepsilon_{i, t}=R_{i, t}-\hat{R_{i, t}}$,

where

$\varepsilon_{i, t}$ is the excess (abnormal) return of firm $i$ at day $t, R_{i, t}$ is the actual (raw) return of firm $i$ at day $t$, and $\tilde{R}_{i, t}$ is the estimated return of firm $i$ at day $t$.

The average abnormal return was calculated as follows:

$$
A R_{t}=1 / N \sum_{i=1}^{N} \varepsilon_{i, t}
$$

where

$A R_{t}$ is the average abnormal return at day $t, N$ is the number of observations, and $\varepsilon_{i, t}$ is the abnormal return of firm $i$ at day $t$.

The CAR over holding periods, from day $m 1$ to day $m 2$, was calculated as follows:

$$
C A R_{m_{1}, m_{2}}=\sum_{t=m_{1}}^{m_{2}} A R_{t},
$$

where

$C A R_{m_{1}, m_{2}}$ is the CAR over the holding period $m 1$ to $m 2$.

\subsubsection{Simultaneous Equation Model}

Nissim and Ziv (2001) and Grullon et al. (2005) individually established models to test whether dividend changes can predict future earnings changes. Although both models regressed future earnings changes on current dividend changes, they differed in their assumptions concerning the mean reversion process of earnings. Nissim and Ziv's model can be described as a linear model, whereas Grullon et al.'s can be portrayed as a nonlinear model. To test the information content of dividend changes on earnings prospects, we individually incorporated the linear and nonlinear models with CAR to form a simultaneous-equation model.

Nissim and Ziv (2001) posited that studies like that of Benartzi et al. (1997) are misspecified due to the "measurement error" in the dependent variable and the "omitted correlated variable" problem. They argued that both measurement errors and model misspecifications might account for adverse effects of dividend signal hypotheses. First, they observed that most studies falsely use the previous market value of equity, which can reflect future earnings too early, as a deflator of subsequent earning changes, and instead employ the previous book value of common stocks in their empirical analysis. Second, as reported in the literature, they defined return on equity (ROE) as a key predicator for earning changes. In particular, the mean reversion of ROE implies decreased future earnings when the current ROE level is higher than its longterm average, and vice versa. Moreover, Nissim and Ziv (2001) assumed that current earnings follow the data generating mechanism of first-order autocorrelation. Accordingly, they specified current ROE as a proxy for omitted correlated variables for future profitability and found robust evidence for the dividend 
signal hypotheses regardless of the dependent variable of future earning changes, future earnings, or future abnormal earnings.

Nissim and Ziv improved the future earning change equations of prior studies, which wrongly assume that earnings follow a random walk with drift. They argued that ROE is an important predictor of future earnings changes and that ROE is mean-reverting (according to Fama and French [2000] and Freeman et al. [1982]). Moreover, the relationship between CAR and future earnings changes may be due to autocorrelation in the earnings change series. Thus, they included $\mathrm{ROE}_{\tau-1}$ and $\mathrm{CE}_{0}=\left(\mathrm{E}_{0}-\mathrm{E}_{-1}\right) / \mathrm{B}_{-1}$ to control for the mean reversion and autocorrelation in earnings but assumed that the rate of mean reversion and the level of autocorrelation are uniform across all observations. Thus, based on Nissim and Ziv's linear model, our linear future equity-scaled earning change equation was established as follows:

First, the dependent variable, which is the market value-scaled change in earnings in years 0,1 , and 2, was regressed with the CARs of dividends (Benartzi et al., 1997). This leads to Model 1.

$$
\left(E_{t}-E_{t-1}\right) / P_{t-1}=\alpha+\beta_{1} C A R_{0}+\varepsilon_{t},
$$

Second, Nissim and Ziv (2001) argued that the insignificant relationships in the future years may be due to the incorrect specification of the model and the measurement error in the dependent variable. They postulated that there should be a control variable in the model, as return on equity is mean-reverting. To remove the error in the dependent variable, one has to use the book value of common equity for scaling earnings changes. Specifically, Model 2 is written as follows:

$$
\left(E_{t}-E_{t-1}\right) / B_{t-1}=\alpha+\beta_{1} C A R_{0}+\beta_{2} R O E_{t-1}+\varepsilon_{t},
$$

Third, another approach is to include the previous year's dependent and independent variables as additional explanatory variables to correct for the autocorrelation. Fama and French (2000) used an estimate of firstorder autocorrelation to arrive at the correct standard errors, while Grullon et al. (2005) used Hansen and Hodrick's (1980) standard error correction method. Therefore, we estimated a regression that allows for different coefficients for dividend release sample and no-dividend release sample. Here, we included the earnings change in year 0 as an additional control variable. The regression Model 3 allows for asymmetric reactions to dividend releases and no-dividend releases, and controls for uniform mean reversion and momentum in earnings. Model 3 is written as follows:

$$
\left(E_{t}-E_{t-1}\right) / B_{t-1}=\alpha+\beta_{1 D R}\left(D R_{0} \times C A R_{0}\right)+\beta_{1 N D R}\left(N D R_{0} \times C A R_{0}\right)+\beta_{2} R O E_{t-1}+\beta_{3} C E_{0}+\varepsilon_{t},
$$

where

$\mathrm{ROE}_{\tau-1}$ is equal to $E_{\tau-1} / \mathrm{B}_{\tau-1}$. According to the hypothesis established in the prior section, $\beta_{1}$ can be positive or negative.

Fourth, in their nonlinear model, Grullon et al. criticised Nissim and Ziv for controlling for a wrong linear form of the mean reversion in earnings, which possibly leads to a spurious positive correlation between CAR and future earnings changes. Their criticism is based on the works of Brooks and Buckmaster (1976), Elgers and Lo (1994), and Fama and French (2000), which find that the mean reversion process of earnings is highly nonlinear. Specifically, Fama and French empirically showed that a model with a nonlinear rate of mean reversion is better than a model with a uniform rate of mean reversion in explaining the evolution of earnings. Thus, Grullon et al. revised Nissim and Ziv's regression model for the nonlinear earnings process by using a modified partial adjustment model proposed by Fama and French (2000). The model suggests that large changes in earnings revert faster than small changes, and that negative changes revert 
faster than positive changes. We established our future equity-scaled earning change equation by employing the same nonlinear mean reversion process of earnings. This leads to Model 4, written as follows:

$$
\begin{aligned}
& \left(E_{t}-E_{t-1}\right) / B_{t-1}=\alpha+\beta_{1 D R}\left(D R_{0} \times C A R_{0}\right)+\beta_{1 N D R}\left(N D R_{0} \times C A R_{0}\right)+ \\
& \left(\chi_{1}+\chi_{2} N D F E D_{0}+\chi_{3} N D F E D_{0} \times D F E_{0}+\chi_{4} P D F E D_{0}\right) \times D F E_{0}, \\
& +\left(\kappa_{1}+\kappa_{2} N C E D_{0}+\kappa_{3} N C E D_{0} \times C E_{0}+\kappa_{4} P C E D_{0} \times C E_{0}\right) \times C E_{0}+\varepsilon_{t}
\end{aligned}
$$

In this model, $\mathrm{DFE}_{0}=\mathrm{ROE}_{0}-\mathrm{E}\left(\mathrm{ROE}_{0}\right)$, where $\mathrm{E}\left(\mathrm{ROE}_{0}\right)$ is the fitted value of $\mathrm{ROE}_{0}$ from the crosssectional regression of ROE on the logarithm of total assets in year ${ }_{\mathrm{t}-1}\left(\log \mathrm{TA}_{\mathrm{t}-1}\right)$, logarithm of the marketto-book ratio of equity in year $t_{-1}\left(\operatorname{logMBV} \mathrm{V}_{\mathrm{t}-1}\right)$, and return on equity in year $\mathrm{t}_{-1}\left(\mathrm{ROE}_{\mathrm{t}-1}\right)$. We have estimated the error from cross-sectional regression in each year. $\mathrm{CE}_{0}$ is equal to $\left(\mathrm{E}_{\mathrm{t}}-\mathrm{E}_{\mathrm{t}-1}\right) / \mathrm{B}_{\mathrm{t}-1}$. NDFED $\left(\mathrm{PDFED}_{0}\right)$ is a dummy variable that takes the value of 1 if $\mathrm{DFE}_{0}$ is negative (positive) and 0 otherwise. Similarly, $\mathrm{NCED}_{0}$ $\left(\mathrm{PCED}_{0}\right)$ is a dummy variable that takes the value of 1 if $\mathrm{CE}_{0}$ is negative (positive) and 0 otherwise. As pointed out by Fama and French (2000), the terms included are meant to capture the nonlinearities in the mean reversion and autocorrelation in earnings.

\section{Results and Analysis}

Table 2 summarises the expectation of the two samples: dividend release and no-dividend release. This study expects to find a positive price impact to dividend release on the announcement day, and no price impact for the no-release sample. This will be interpreted by the market as a signal that managers have insider information about the firm's earnings, while before the announcement day, no price impact is expected - this is an indication of no information leakage. Table 2 presents a summary of the main expectations regarding the two samples.

Insert Table 2

Table 3 reports a summary of the results for the market model. It shows the mean abnormal return per cent (MAR \%), its associated $t$-statistics, and its $p$-value (the significance of MAR) on and around the announcement date of the dividend release sample. Significant abnormal return is observed on days 0 and 1 at the $1 \%$ significance level. The mean abnormal return is $2.940 \%$ and $0.636 \%$ with $t$-statistics of 19.93 and 4.30, respectively. The overall market reaction on days 0 and 1 is positive. This proves the hypothesis that there is a significant positive abnormal return on the dividend release announcement days. The results show that there is an overreaction immediately after the announcement day, then a post-event correcting attempt, and then a return to normal. As a result, the market reacts positively to dividends announcements, which is consistent with the signalling hypothesis.

Table 3 also shows the mean abnormal return per cent (MAR \%) employing the market model, $t$-statistics, and its $p$-value (the significance of MAR) for the no-dividend release sample. No significant abnormal return is observed on and around the announcement days. The overall MAR post announcement is not high or significant. Furthermore, the differences in MAR between the two samples are significant on and around the announcement day, specifically on days $-1,0,1$, and 2 . This indicates that the two samples react differently to dividends releases. This supports the signalling hypothesis and accepts the hypothesis for the no-dividend release sample that there is no significant change in the abnormal return on and around the announcement days. Figure 1 shows graphically the MAR for dividend release and dividend no-release samples. They show that the market reaction is positively related to dividend release announcements. The market reacts positively to its highest point when announcing dividends, which is around $3 \%$ on day 0 . Also, the figures show that there is no information leakage before the announcement day for the two samples. The results also support the signalling hypothesis that no market reaction is associated with no- 
dividends release. In the context of the wider literature, our support of the signalling hypothesis is consistent with the empirical evidence for developed and developing markets (Watts, 1973; Gonedes, 1978; Penman, 1983; DeAngelo et al., 1996; Benartzi et al., 1997; El-Khouri \& Almwalla, 1997; Mullah, 2001; Nissim \& Ziv, 2001; Grullon et al., 2002; Omet \& Abu-Ruman, 2003; Brav et al., 2005; Grullon et al., 2005; Denis \& Osobov, 2008; Braggion \& Moore, 2011; and AlShattarat et al., 2012).

\section{Insert Table 3 and Figure 1}

Table 4 reports a summary of the mean CAR on and around the announcement date for dividends announcements (dividend release and no-dividend release samples) for different holding periods. The $t$ statistics test is used to report the results. The CAR is based on the market model. The table reports the testholding periods used; the holding period used to test the significance is between five days before and five days after the announcement day (the whole test period). Furthermore, it reports the CAR and its $t$ - statistics for dividend release and no-dividend release samples. The results show that CARs are significantly positive at the $1 \%$ level for all selected holding periods. Furthermore, the differences in MAR between the two samples are significant for the selected holding periods. Again, this is an indication that the two samples react differently to dividends releases. This result supports the hypothesis that there is a significant positive CAR related to dividend release announcements (H1a hypothesis). Again, this result reported from CAR supports the signalling hypothesis. The table also shows the CAR and $t$-test statistics for the no-dividend release sample. No significance is reported in the designated test periods, which supports the hypothesis (H1b) that there is not a significant change in the CAR after the no-dividend release announcements. Again, this result reported from CAR supports the signalling hypothesis. Overall, the results show that the market reacts significantly to dividend release on the announcement day. Figure 2 shows graphically the CAR for dividend release and no-dividend release samples. It shows that the market reaction is positively related to dividend release announcements, and no market reaction is associated with no-dividend release sample.

\section{Insert Table 4 and Figure 2}

To address more precisely whether managers use dividends announcements to signal firm earnings prospects, we individually estimated the linear and nonlinear equation models using the 2SLS method with year fixed effects and clustered standard errors by firm. The results are presented in Tables 5 and 6 .

Table 5 presents the results of regression analysis of earnings changes scaled by market value on dividends announcements. We have used the simple linear model proposed by Nissim and Ziv (2001) as well as the nonlinear model suggested by Fama and French (2000) to estimate the expected earnings. The dependent variable in the regressions is change in earnings in years 0,1 , and 2 scaled with the market value at the beginning of year 0 (Benartzi et al., 1997). The independent variable in the regression is the CAR in year 0 . The regression for year 0 provides evidence for a positive relationship between earnings changes and dividends announcements. Similarly, we found a positive relationship in year 1, while the relationship between earnings changes and dividends announcements is insignificant in year 2 . This provides evidence that dividends announcements are used as a signal about future earnings, but this is limited to one year only after dividends announcements. The results indicate that dividends are adjusted based on long-term earnings prospects. That could be due to the fact that managers have future information on their corporation's income when they announce dividends to the market. Our results are consistent with Grullon et al. (2005) and Lukose and Rao (2010).

Insert Table 5 
Table 6 presents the results of simultaneous regression models for dividends announcements and future earnings changes scaled by book value. The results reported in Table 6 are similar to those reported in Table 5.

Regarding Model 2 in Table 6, Nissim and Ziv (2001) argued that the insignificant relationships in future earnings may be due to the incorrect specifications of the model and the measurement error in the dependent variable. Their argument was to include a control variable in the model, as return on equity is meanreverting. Initially, our model was estimated by two-stage least squares (2SLS). The $R 2$ is 14.4 per cent and 18.8 per cent for $t=1$ and $t=2$, respectively, which implies that the model explains a significant proportion of the variation in future earnings changes. The results show a positive relationship between dividends announcements and future earnings in $t=1$ at the $1 \%$ significance level, while the relationship between the two variables is insignificant in $t=2$. The interpretation of the marginal effect is that a 1 per cent increase in the market reaction of dividends, other things being equal, leads to an increase of 6.4 per cent in future earnings, indicating that dividends are an important factor affecting future earnings in $t=1$, but it has no impact on $t=2$. The results are consistent with Model 1 presented in Table 4.

Model 3 in Table 5 extends the analysis by splitting dividends announcements into two groups; dividends release and no-dividends release. The $R 2$ is 10.9 per cent and 16.9 per cent for $t=1$ and $t=2$, respectively, which implies that the model explains a significant proportion of the variation in future earnings change. Interestingly, the results of the dividends announcements have a positive relationship with future earnings changes at the $1 \%$ significance level, which indicates that the marginal increase of 1 per cent in the market reaction of dividends release, other things being equal, leads to an increase of 7.4 per cent in future earnings in $t=1$ and no impact in $t=2$. The coefficient is significant for the dividend release sample and insignificant for the no-dividend release sample for $t=1$ and $t=2$. The results are consistent with Model 3 and with the extant literature from developed and emerging markets. The results support hypotheses $\mathrm{H} 2 \mathrm{a}$ and $\mathrm{H} 2 \mathrm{~b}$, that CARs for dividend release are associated with future equity-scaled earnings increase, and vice versa for nodividend releases. This is an indication that managers signal the future earnings prospects in terms of dividend change. The signal affects the first year's future earnings and will be adjusted in the second year, since investors could take actions to adjust the market price and managers might be conservative about signalling long-term future earnings. This supports the signalling hypothesis of future earnings in the short term.

Furthermore, to test the robustness of our model, we applied the nonlinear model suggested by Grullon et al. (2005), reported in Table 5 under Model 4. Grullon et al. revised Nissim and Ziv's regression model for the nonlinear earnings process by using a modified partial-adjustment model proposed by Fama and French (2000). The model has implications that large changes in earnings revert faster than small changes and the negative changes revert faster than positive changes. The coefficient of future equity-scaled earnings changes $\left(\beta_{I D R}\right)$ is positive at 4.88 per cent and significant at the $1 \%$ significance level for $t=1$, while the coefficient is not significant for $t=2$. The results for the coefficient $\left(\beta_{1 N D R}\right)$ are not significant for both $t=1$ and $t=2$. The $R 2$ is 18.7 per cent and 25.6 per cent for $t=1$ and $t=2$, respectively, which implies that the model explains a significant proportion of the variation in future earnings change. The results are similar to those reported in Model 3 in Table 6. This indicates the robustness of our results.

In conclusion, managers release dividends to signal firms' earnings prospects. However, even if managers do announce dividends in order to signal the earnings prospects of their firms, it is still difficult for investors to exactly identify the motive. Therefore, whether dividends release can predict a firm's earnings prospects becomes a distinct issue and is tested in this model system using the estimated future equity-scaled earning change equation (Models 3 and 4, Table 6). We find that all of the coefficients are insignificant for $t=1$ and $t=2$ in both linear and nonlinear model systems except for $\beta_{I D R}$ in $t=1$, which is positive at the $1 \%$ significance level. The results show that dividends release can serve as a tool to predict firm equity-scaled 
earnings prospects in the short term. This supports the signalling hypothesis and, thus, dividends release has been proved to be a prospective signalling device that managers may use.

Insert Table 6

\section{Robustness Tests}

One of the major performance metrics used to measure firm performance is ROA. As dividend signalling theory does not indicate precisely which performance measure should be the information that managers want to communicate to investors (e.g., future income or future profitability), we replicated the simultaneous-equation model system, replacing the change in equity-scaled earnings with the change in asset-scaled earnings. Indeed, asset-scaled earnings (ROA) are widely used as well to measure firm performance because equity-scaled earnings are sensitive to changes in capital structure while asset-scaled earnings are not and because asset-scaled earnings are not affected by factors such as special items (i.e., unusual and nonrecurring items reported before taxes), accounting for minority interest, and income taxes. Barber and Lyon (1996) provided theoretical justification for using the operating performance over the earnings when measuring firm performance. Further, they reported that change models always dominate level models with better statistical properties. Fama and French (2000), Nissim and Ziv (2001), and Grullon et al. (2005) used the same method in their analyses. For consistency, we also replaced the ROE in the model system with ROA to examine the relationship between dividend changes and changes in future profitability. So, to complement our earlier analysis, we have defined ROA as the operating income before depreciation and amortization, scaled by the book value of total assets. As a cleaner measure that is relatively free from accounting manipulations and capital structure changes, this provides a better understanding of the relationship between dividend changes and profitability. In the following linear and nonlinear regression models, we replicate all of the previous analyses by replacing earnings with ROAt as the dependent variable. Table 7 presents the estimated model system.

As for the test of the predictive ability of dividend changes on ROA changes reported in Table 7, the results are consistent with our results reported in Table 6 . We found a significant positive relationship between dividend changes and ROA changes in year 1. Grullon et al. (2005) reported an insignificant relationship between dividend changes and ROA changes in year 1. But for year 2, our models report an insignificant relationship between dividend changes and ROA changes. The results are the same when applying a nonlinear model. The results indicate that an increase in dividends, for example, predicts a forthcoming increase in ROA. The more the dividend increases, the more the ROA increases. Because the change in dividends had been shown to be for the purpose of signalling ROA changes, it is beneficial to a firm's future ROA because it increases the funds available for potential investment opportunities that are not subject to the capital structure of firms.

Insert Table 7

\section{Conclusion}

This study empirically examines the signalling theory for a sample of firms listed on the ASE during the period 2009 to 2015 . The sample consists of 264 observations - 184 observations for dividend release and no-dividend release, respectively. ESM is applied to examine the market reaction to dividend release announcements. The market model is used to generate the expected returns. Also, the $t$-test is used to examine the significance of the mean and CAR. Results from the dividend release sample show that there is a significant positive abnormal return on the announcement days. They also show that there is an overreaction immediately after the announcement day, then a post-event correcting attempt, and then a return to normal, which is consistent with the signalling hypothesis. For the no-dividend release sample, the results show no significant abnormal return on and around the announcement days, which is again 
consistent with the signalling hypothesis. Furthermore, the dividend signalling hypothesis implies that future earnings changes can be predicted by current dividends announcements. This implication is based on the foundation that managers announce dividends to signal earnings prospects to investors. If managers announce dividends for other reasons and this affects future earnings, the positive information content of dividends announcements about earnings prospects can no longer serve as strong evidence for the signalling hypothesis. Therefore, if managers announce dividends on the basis of their future earnings changes to signal their profitability to investors, the impact of dividends announcements on future earnings may encounter a mutually endogenous problem between the two variables. The OLS estimation model may lead to biased results. This study addresses this problem by formulating a simultaneous equation model system and applying the 2SLS method to its estimation. We find that, regardless of the model systems (linear or nonlinear), the signalling hypothesis is strongly supported in the short run because a significant positive relationship between dividend changes and future earnings has been reported in year 1 .

In applying the ESM methodology, the findings of the information content of dividends show that there is a significant positive market reaction to dividends announcements, which supports the signalling hypothesis. Also, the findings present a strong relationship between dividends announcements and profitability in the year of announcements and the subsequent year, whereas this relationship does not exist in the second year following announcements. Our findings show that there is value relevance for dividends, thus supporting the signalling hypothesis in the short run. As for the test of the predictive ability of dividend changes on ROA changes, we find a significant positive relationship between dividend changes and ROA changes in year 1 . But for year 2, our models report an insignificant relationship between dividend changes and ROA changes. The results are the same when applying a nonlinear model. The results indicate that an increase in dividends, for example, predicts a forthcoming increase in ROA. The more the dividend increases, the more the ROA increases. Because the change in dividends had been shown to be for the purpose of signalling ROA changes, it is beneficial to a firm's future ROA because it increases the funds available for potential investment opportunities and is not subject to the capital structure of firms. Moreover, our findings suggest that investors recognise the signalling purpose and find that dividends announcements are useful in predicting the favourable and unfavourable future earnings in the short run (the same year and the subsequent year), and managers may use dividends to signal the earnings prospects of their firms in anticipation of expected market benefits.

This study supports the signalling hypothesis in the short run (the current year and subsequent year). These findings could have significant policy implications. Support for a signalling effect implies an existence of information symmetry, at least theoretically, between management and investors. On the other side, this study could not reflect the levels of inside ownership or the existence of signalling substitutes. Despite this, these findings could have implications for Jordan's existing corporate governance practices and firms' disclosure environment.

There are obvious limitations of any country-specific analysis. This study has tested how well the general models were able to explain the particular case of Jordan. The results are specific to Jordan, but they do shed light on the generality of the rival models of dividend policy. Many of the structural characteristics of the capital market in Jordan are, however, also present in other emerging markets. The results from this study may therefore help to provide the basis for comparative research, both in the region and in other emerging markets. Our understanding of the unique characteristics of emerging markets may be increased by a re-evaluation of the models that were developed primarily to aid our understanding of developed markets. Additional theoretical modelling of developing markets, in conjunction with empirical testing, can only contribute to knowledge.

\section{References}


Abdulla, J. (1992), "Focus on dividend practices of Omani firms: Survey findings", Journal of Finance Management and Analysis, Vol. 5, No. 1, pp. 23-32.

Adelegan, O. (2000), "An empirical analysis of the relationship between cash flow and dividend changes in Nigeria", a paper presented at the 23rd Annual Congress of the European Accounting Association in Munich, 28-31 March.

Afza, T. and Mirza, H. (2010), "Ownership structure and cash flows as determinants of corporate dividend policy in Pakistan", International Business Research, Vol. 3 No. 3.

Aharony, J., Falk, H., and Swary, I. (1988), "Information content of dividend increases: The case of regulated utilities”, Journal of Business Finance and Accounting, Vol. 15, No. 3, pp. 401-14.

Aharony, J., and Swary, I. (1980), "Quarterly dividend and earnings announcements and stockholders' returns: An empirical analysis", Journal of Finance, Vol. 35, pp. 1-12.

Ahmed, H. and Attiya, J. (2009), "Dynamics and determinants of dividend policy in Pakistan (evidence from Karachi Stock Exchange non-financial firms)", International Journal of Finance and Economics, No. 25, pp. 148-171.

Aivazian, V., Booth, L., and Cleary, S. (2003), "Do emerging market firms follow different dividends policies from US firms?”, The Journal of Financial Research, Vol. 26, No. 4, pp 371-87.

Al-Najjar, B. (2009), "Dividend behaviour and smoothing: evidence from Jordanian panel data", Studies in Economics and Finance, Vol. 26 No. 3, pp. 182-197.

AlShattarat, W., Atmeh, M., and AlShattarat, B. (2012), "Dividend signalling hypothesis in emerging markets: more empirical evidence", Journal of Applied Business Research, Vol. 29, No. 2, pp. 461-467.

Al-Yahyaee, K., Pham, T. and Walter, T. (2006), "Capital structure and dividend policy in a personal tax free environment: the case of Oman", unpublished PhD. Dissertation, University of New South Wales.

Asquith, P., and Mullins, D. (1983), "The impact of initiating dividend payments on shareholders' wealth", Journal of Business, Vol. 56, pp. 77-96.

Ayub, M. (2005), "Corporate governance and dividend policy", Pakistan Economic and Social Review, Vol. 48 No. 1, pp. 115-128.

Bajaj, M., and Vijh, A. (1990), "Dividend clienteles and the information content of dividend changes", Journal of Financial Economics, Vol. 26, pp. 193-219.

Baker, H., Powell, G., and Veit, E. (2002), "Revisiting managerial perspectives on dividend policy", Journal of Economics and Finance, Vol 26, No. 3, pp. 267-83.

Barber, B., and Lyon, J. (1996), "Detecting abnormal operating performance: The empirical power and specification of test statistics”, Journal of Financial Economics, Vol. 41, No. 3, pp. 359-399.

Bhattacharya, S. (1979), "Imperfect information, dividend policy, and the bird in the hand fallacy", The Bell Journal of Economics, Vol. 5, No. 1, pp. 259-70. 
Benartzi, S., Michaely, R., and Thaler, R., (1997), “Do changes in dividends signal the future or the past?”, Journal of Finance, Vol. 52, No. 3, pp. 1007-1034.

Booth, L., Aivazian, V., Demirguc-Kunt, A. and Maksimovic, V. (2001), "Capital structures in developing countries", The Journal of Finance, Vol. 56, pp. 87-130.

Borde, S., Byrd, A., and Atkinson, S. (1999), "Stock price reaction to dividend increases in the hotel and restaurant sector", Journal of Hospitality and Tourism Research, Vol. 23, No. 1, pp. 40-52.

Braggion, F. and Moore, L. (2011), "Dividend policies in an unregulated market: The London Stock Exchange", Review of Financial Studies, Vol. 24, pp. 2935-2973.

Brav, A., Graham, J., Harvey, C., and Michaely, R. (2005), "Pay-out policy in the 21st century", Journal of Financial Economics, Vol. 77, No. 3, pp. 483-527.

Brooks, L., and Buckmaster, D. (1976), "Further evidence on the time series properties of accounting income", Journal of Finance, Vol. 31, No. 5, pp. 1359-1373.

Chen, T., and Kao, L. (2014), "Dividend changes and information about future profitability: an application of difference GMM", Applied Economics Letters, Vol. 21, No. 7, pp.505-508.

Dasilas, A., (2007), "Stock market reaction to dividend announcements: Evidence from the Greek Stock Market", Working Paper, available at http://papers.ssrn.com/sol3/papers.cfm?abstract_id=981885\&rec $=1 \&$ srcabs=955768.

DeAngelo, H., DeAngelo, L., and Skinner, D. (1996), "Reversal of fortune: dividend signalling and the disappearance of sustained earnings growth", Journal of Financial Economics, Vol. 40, pp. 341-371.

Denis, D., and Osobov, I. (2008), "Why do firms pay dividends? International evidence on the determinants of dividend policy", Journal of Financial Economics, Vol. 89, pp. 62-82.

El-Khouri, R. and Almwalla, M. (1997), "The effect of dividend changes on security prices: The case of Jordanian companies", Abhath Al-Yarmouk, Vol. 13, No. 1B, pp. 87-94.

Eades, K., Hess, P., and Kim, E. (1985), "Market rationality and dividend announcements", Journal of Financial Economics, Vol. 14, pp. 581-604.

Elgers, P., and Lo, M. (1994), "Reductions in analysts' annual earnings forecast errors using information in prior earnings and security returns", Journal of Accounting Research, Vol. 32, pp. 290-303.

Fama, E., and French, K. (2000), "Forecasting profitability and earnings", Journal of Business, Vol. 73, pp.161-175.

Freeman, R., Ohlson, J., and Penman, S. (1982), "Book rate-of-return and prediction of earnings changes: An empirical investigation”, Journal of Accounting Research, Vol. 20, pp. 639-653.

Fukuda, A. (2000), "Dividend changes and earnings performance in Japan”, Pacific-Basin Finance Journal, Vol. 8, No. 1, pp. 53-66.

Gonedes, N. (1978), "Corporate signalling, external accounting, and capital market equilibrium: Evidence on dividends, income, and extraordinary items", Journal of Accounting Research, Vol. 16, pp. $26-79$. 
Gordon, M. (1962), “The investment, financing, and valuation of the corporation”, Homewood, IL: Richard D. Irwin.

Grullon, G., and Michaely, R. (2004), "The information content of share repurchase programs", Journal of Finance, Vol. 59, pp. 651-680.

Grullon, G., Michaely, R., Benartzi, S., and Thaler, R. (2005), "Dividend changes do not signal changes in future profitability”, Journal of Business, Vol. 78, pp. 1659-1682.

Grullon, G., Michaely, R. and Swaminatham, B. (2002), “Are dividend changes a sign of firm maturity?", Journal of Business, Vol. 75 No. 3, pp. 387-424.

Hansen, L., and Hodrick, R. (1980), "Forward exchange rates as optimal predictors of future spot rates: An econometric analysis", Journal of Political Economy, Vol. 88, No. 5, pp. 829-853.

Harada, K., Nguyen, P. (2005), "Dividend change context and signaling efficiency in Japan", Pacific-Basin Finance Journal, Vol. 13, pp. 504-522.

Healy, P., and Palepu, K. (1988), "Earnings information conveyed by dividend initiation and omissions", Journal of Financial Economics, Vol. 21, No. 2, pp. 149-75.

Huang, C., You, C. and Hsiao, H. (2017), "Dividends and Subsequent Profitability: An Examination of a Dual Dividend Stock Market", Review of Pacific Basin Financial Markets and Policies, Vol. 20, No. 01, p.1750002.

Impson, M. (1997), "Market reaction to dividend-decrease announcements: Public utilities vs. unregulated industrial firms", The Journal of Financial Research, Vol. 20, No. 3, pp. 407-22.

Jensen, M. (1986), “Agency costs of free cash flow, corporate finance, and takeovers", American Economic Review, Vol. 76, pp. 323-329.

Jensen, M. (1988), "Agency costs of free cash flow, corporate finance, and the market for takeovers", American Economic Review, Vol. 76, pp. 323-329.

Jensen, M. and Meckling, W. (1976), "Theory of the firm: managerial behaviour, agency costs and ownership structure", Journal of Financial Economics, Vol. 3 No. 2, pp. 305-360.

John, K. and Williams, J. (1985), "Dividends, dilution, and taxes: A signalling equilibrium", The Journal of Finance, Vol. 40, No. 4, pp. 1053-1070.

Kalay, A., and Loewenstein, U. (1985), "Predictable events and excess returns: The case of dividend announcements", Journal of Financial Economics, Vol. 14, pp. 423-449.

Liu, C., and Chen, A. (2015), "Do firms use dividend changes to signal future profitability? A simultaneous equation analysis", International Review of Financial Analysis, Vol. 37, pp. 194-207.

Lukose, J., and Rao, S. (2010), "Dividend changes and profitability: an empirical study of Indian manufacturing firms", The IUP Journal of Applied Finance, Vol. 16, No. 1, pp. 1-25. 
McCaffrey, K., and Hamill, P. (2000), "Dividend initiation announcements effects in initial public offerings", Applied Financial Economics, Vol. 10, pp. 533-542.

Michaely, R., Thaler, R., and Womack, K. (1995), "Price reaction to dividend initiation and omissions: Overreaction and drift?", The Journal of Finance, Vol. 50, No. 2, pp. 573-608.

Miller, M., and Modigliani, F. (1961), "Dividend policy, growth, and the valuations of shares", The Journal of Business, Vol. 34, No. 4, pp. 411-433.

Miller, M. and Rock, K. (1985), "Dividend policy under asymmetric information", The Journal of Finance, Vol. 40, No. 4, pp. 1031-1051.

Mullah, A. (2001), "Dividend policy and behaviour, and security price reaction to the announcement of dividends in an emerging market: A study of companies listed on the Dhaka stock exchange", PhD thesis, Business School, University of Leeds, UK.

Nissim, D., and Ziv, A. (2001), "Dividend changes and future profitability", Journal of Finance, Vol. 56, No. 6, pp. 2111-2133.

Omet, G. (2004), "Dividend policy behavior in the Jordanian capital market", International Journal of Business, Vol. 9 No. 3, pp. 287-299.

Omet, G. and Abu-Ruman, G. (2003), "Dividend policy in the Jordanian capital market: Empirical findings and survey results", Second International Finance Conference, 13-15 March, Tunisia.

Penman, S. (1983), "The predictive content of earnings forecasts and dividends", Journal of Finance, Vol. 38, pp. 1181-1199.

Peterson, P. (1989), "Event studies: A review of issues and methodology", Quarterly journal of business and economics, pp.36-66.

Petit, R. (1972), “Dividend announcements, security performance, and capital market efficiency”, Journal of Finance, Vol. 27, pp. 993-1007.

Travlos, N., Trigeorgis, L., and Vafeas, N. (2001), "Shareholder wealth effects of dividend policy changes in an emerging stock market: the case of Cyprus", Multinational Finance Journal, Vol. 5, No. 2, pp. 87112.

Watts, R. (1973), “The information content of dividends”, Journal of Business, Vol. 46, pp. 191-211.

Zurigat, Z. and Gharaibeh, M. (2011), "Do Jordanian firms smooth their dividends? Empirical test of symmetric and asymmetric partial adjustment models", International Research Journal of Finance and Economics, No. 81. 
Table 1: Final sample

\begin{tabular}{cc}
\hline Samples & Observations \\
\hline Dividends Release (DR) & 264 \\
No Dividends Release (NDR) & 184 \\
Total & 448 \\
\hline
\end{tabular}

Table 2: Summary of the expected mean abnormal return and cumulative abnormal return

\begin{tabular}{cccc}
\hline \multirow{2}{*}{ Dividend } & Expected $M A R_{(\tau=0)}$ & \multicolumn{2}{c}{ Expected $C A R_{m 1, m 2}=0$} \\
\cline { 3 - 4 } & & Per-event & Post-event \\
\hline $\begin{array}{l}\text { Dividend } \\
\text { Released }\end{array}$ & Positive: MAR $>0$ & No Change: $C A R_{-5,-1}=0$ & Positive: $C A R_{0,5}>0$ \\
No & & & \\
$\begin{array}{l}\text { Dividend } \\
\text { Released }\end{array}$ & No change: MAR $=0$ & No Change: $C A R_{-5,-1}=0$ & No Change: $C A R_{0,5}=0$ \\
\hline MAR is the mean abnormal return; $C A R$ is the cumulative abnormal return &
\end{tabular}

Table 3: Mean abnormal return of dividend release and no-dividend release samples 


\begin{tabular}{|c|c|c|c|c|c|c|c|c|}
\hline \multirow[t]{2}{*}{ Days } & \multicolumn{3}{|c|}{$\begin{array}{l}\text { Dividend Release Sample } \\
\qquad \mathrm{N}=264\end{array}$} & \multicolumn{3}{|c|}{$\begin{array}{l}\text { No-Dividend Release } \\
\text { Sample } \\
\mathrm{N}=184\end{array}$} & \multicolumn{2}{|c|}{ Difference In Means } \\
\hline & MAR \% & t-test & P-value & MAR \% & t-test & P-value & MAR \% & t-test \\
\hline-5 & 0.048 & 0.32 & 0.348 & -0.055 & -0.27 & 0.737 & 0.103 & 0.68 \\
\hline-4 & 0.029 & 0.19 & 0.400 & 0.234 & 1.14 & 0.109 & -0.205 & 1.34 \\
\hline-3 & 0.038 & 0.26 & 0.374 & 0.022 & 0.10 & 0.433 & 0.016 & 0.11 \\
\hline-2 & 0.036 & 0.25 & 0.755 & 0.162 & 0.79 & 0.194 & -0.158 & 1.10 \\
\hline-1 & 0.080 & 0.54 & 0.270 & -0.171 & -0.84 & 0.361 & $-0.281^{*}$ & 1.89 \\
\hline 0 & $2.940^{* *}$ & 19.93 & 0.000 & 0.005 & 0.02 & 0.466 & $2.935^{* *}$ & 19.89 \\
\hline 1 & $0.636^{* *}$ & 4.30 & 0.000 & -0.010 & -0.05 & 0.910 & $0.646^{* *}$ & 4.36 \\
\hline 2 & $0.293^{*}$ & 1.99 & 0.035 & -0.047 & -0.23 & 0.772 & $0.340^{*}$ & 2.31 \\
\hline 3 & 0.147 & 1.00 & 0.140 & 0.073 & 0.36 & 0.336 & 0.074 & 0.50 \\
\hline 4 & 0.198 & 1.34 & 0.151 & 0.066 & 0.26 & 0.259 & 0.132 & 0.89 \\
\hline 5 & $0.291^{*}$ & 1.97 & 0.018 & 0.183 & 0.88 & 0.219 & 0.108 & 0.73 \\
\hline
\end{tabular}

MAR is the mean abnormal return; * Significant at the 5 percent level, ** Significant at the 1 percent level, MAR values are in percentage

Table 4: Summary of the cumulative abnormal return on and around the dividend announcements Dividend Release Sample No Dividend Release Sample Difference In Means

\begin{tabular}{|c|c|c|c|c|c|c|}
\hline \multirow[t]{2}{*}{$\begin{array}{l}\text { Holding } \\
\text { Period }\end{array}$} & \multicolumn{2}{|c|}{$\mathrm{N}=264$} & \multicolumn{2}{|c|}{$\mathrm{N}=184$} & & \\
\hline & CAR \% & t-test & CAR $\%$ & t-test & CAR\% & t-test \\
\hline$(-5,5)$ & $4.736^{* *}$ & 6.16 & 0.462 & 0.58 & $4.274^{* *}$ & 5.55 \\
\hline$(0,5)$ & $4.505^{* *}$ & 5.86 & 0.27 & 0.34 & $4.165^{* *}$ & 5.42 \\
\hline$(0,2)$ & $3.869^{* *}$ & 5.03 & -0.052 & -0.07 & $3.939^{* *}$ & 5.12 \\
\hline$(2,2)$ & $3.985^{* *}$ & 5.18 & -0.061 & -0.08 & $4.065^{* *}$ & 5.28 \\
\hline
\end{tabular}




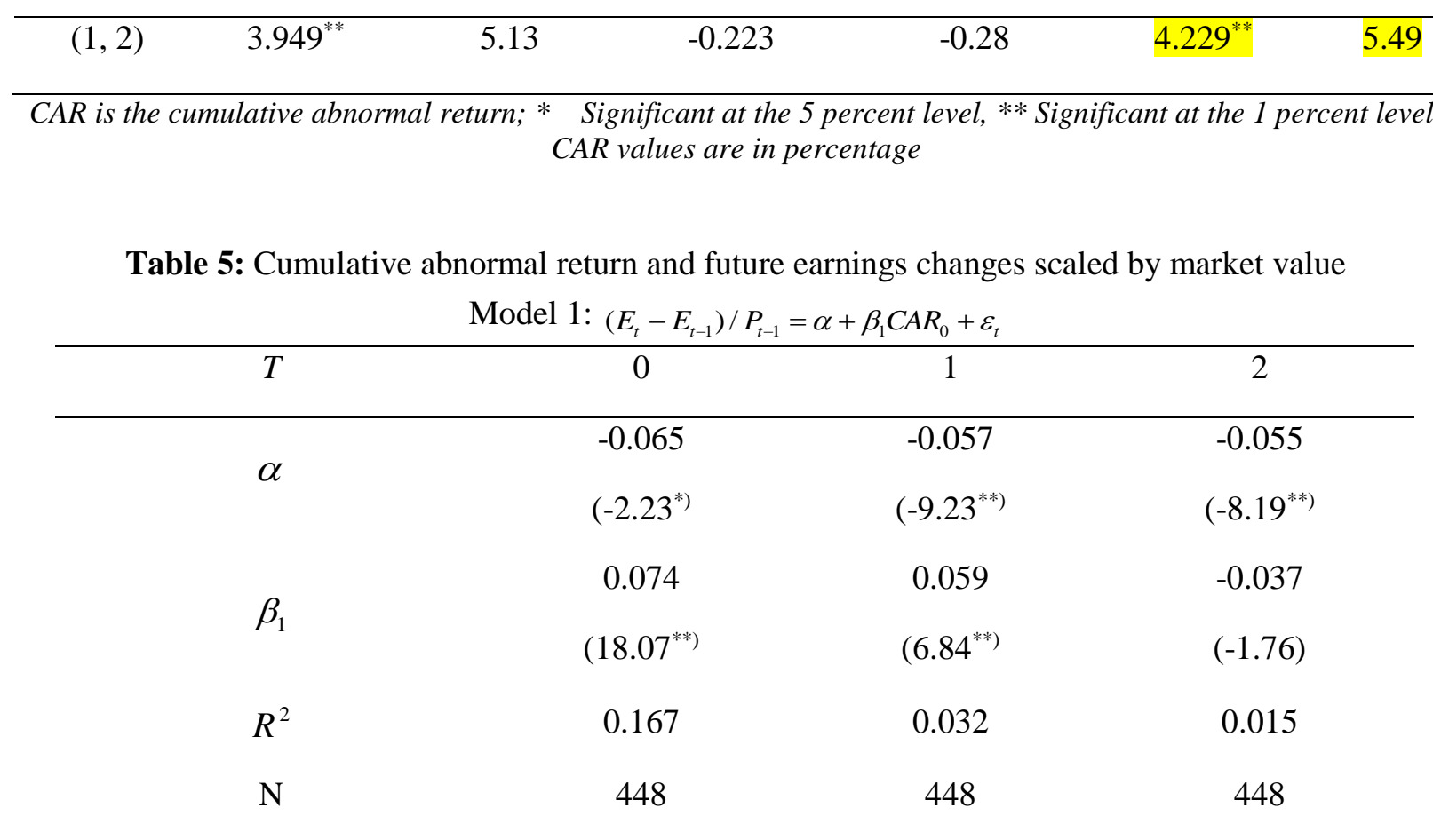

$E_{t}$ denotes the income before interest and tax excluding the extraordinary items, $T$ represents year $0, P_{t-1}$ is the market value of equity at the end of year $t-1, C A R_{0}$ is the cumulative abnormal return for days $(-5,5)$. $t$-statistics are reported in parentheses, * significant at $5 \%, * *$ significant at $1 \%$.

Table 6: Simultaneous regression model (linear and nonlinear) for cumulative abnormal return and future equity-scaled earnings changes

Model 2: $\left(E_{t}-E_{t-1}\right) / B_{t-1}=\alpha+\beta_{1} C A R_{0}+\beta_{2} R O E_{t-1}+\varepsilon_{t}$

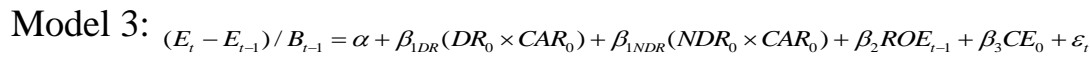

Model 4: $\left(E_{t}-E_{t-1}\right) / B_{t-1}=\alpha+\beta_{1 D R}\left(D R_{0} \times C A R_{0}\right)+\beta_{1 N D R}\left(N D R_{0} \times C A R_{0}\right)+$

$\left(\chi_{1}+\chi_{2} N D F E D_{0}+\chi_{3} N D F E D_{0} \times D F E_{0}+\chi_{4} P D F E D_{0}\right) \times D F E_{0}$

$+\left(\kappa_{1}+\kappa_{2} N C E D_{0}+\kappa_{3} N C E D_{0} \times C E_{0}+\kappa_{4} P C E D_{0} \times C E_{0}\right) \times C E_{0}+\varepsilon_{t}$ 


\begin{tabular}{|c|c|c|c|c|c|c|}
\hline & \multicolumn{2}{|c|}{ Model 2} & \multicolumn{2}{|c|}{ Model 3} & \multicolumn{2}{|c|}{ Model 4} \\
\hline & $t=1$ & $t=2$ & $t=1$ & $t=2$ & $t=1$ & $t=2$ \\
\hline \multirow{2}{*}{$\alpha$} & -0.041 & 0.092 & 0.048 & 0.023 & -0.184 & -0.03 \\
\hline & $(-0.45)$ & $(1.12)$ & (0.98) & $(0.85)$ & $(-0.84)$ & $(-1.18)$ \\
\hline \multirow{2}{*}{$\beta_{1}$} & 0.064 & -0.044 & & & & \\
\hline & $\left(3.32^{* *}\right)$ & $(-1.32)$ & & & & \\
\hline \multirow{2}{*}{$\beta_{2}$} & -0.050 & -0.037 & -0.075 & -0.037 & & \\
\hline & $(-0.98)$ & $(-1.08)$ & $(-1.35)$ & $(-1.14)$ & & \\
\hline \multirow{2}{*}{$\beta_{1 D R}$} & & & 0.074 & 0.044 & 1.117 & 0.064 \\
\hline & & & $\left(5.46^{* * *}\right)$ & $(1.34)$ & $\left(4.88^{* *}\right)$ & $(1.56)$ \\
\hline \multirow{2}{*}{$\beta_{1 N D R}$} & & & 0.012 & 0.026 & 0.011 & 0.047 \\
\hline & & & $(1.54)$ & $(0.15)$ & $(0.46)$ & $(1.29)$ \\
\hline \multirow{2}{*}{$\beta_{3}$} & & & 0.092 & 0.027 & & \\
\hline & & & $(1.38)$ & $(0.35)$ & & \\
\hline \multirow{2}{*}{$\chi_{1}$} & & & & & -0.319 & 0.173 \\
\hline & & & & & $(-1.39)$ & $(0.81)$ \\
\hline \multirow{2}{*}{$\chi_{2}$} & & & & & 0.339 & -0.587 \\
\hline & & & & & $(1.28)$ & $(-1.43)$ \\
\hline \multirow{2}{*}{$\chi^{3}$} & & & & & 0.532 & 0.191 \\
\hline & & & & & (1.19) & $(0.75)$ \\
\hline \multirow{2}{*}{$\chi_{4}$} & & & & & 0.774 & -0.280 \\
\hline & & & & & $(0.29)$ & $(-0.27)$ \\
\hline \multirow{2}{*}{$\kappa_{1}$} & & & & & 0.201 & -0.026 \\
\hline & & & & & $(1.21)$ & $(-0.77)$ \\
\hline \multirow{2}{*}{$\kappa_{2}$} & & & & & -0.194 & 0.114 \\
\hline & & & & & $(-0.84)$ & $(0.62)$ \\
\hline$\kappa_{3}$ & & & & & -0.094 & -0.189 \\
\hline
\end{tabular}




\begin{tabular}{ccccccc}
\hline$\kappa_{4}$ & & & & $(-0.22)$ & $(-0.73)$ \\
$R^{2}$ & 0.144 & 0.188 & 0.109 & 0.169 & -0.601 & -0.747 \\
$N$ & 448 & 448 & 448 & 448 & 448 & 4.187 \\
\hline
\end{tabular}

$\bar{E}_{t}$ denotes the income before interest and tax excluding the extraordinary items at the end of year $t$ after dividends release year, $B_{t-1}$ is the book value of equity at the end of year $t$-1 the beginning of dividends release year, $C A R_{0}$ is the cumulative abnormal return for days $(-5,5), D R$ and NDR are dummy variables that equals 1 for $D R(N D R)$ and 0 otherwise, $R O E_{t-1}$ is equal to $E_{t}{ }_{1} / B_{t}-{ }_{1}$. $C E_{0}=\left(E_{0}-E_{-1}\right) / B_{-1}$. DFE $E_{0}=R O E_{0}-E\left[R O E_{0}\right]$. E[ROE $\left.E_{0}\right]$ is the fitted value from the cross-sectional regression of $R O E_{0}$ on the logarithm of total equity in year-1, the logarithm of the market-to-book ratio of equity in year -1, and $R O E_{-1}$. PDFED $D_{0}\left(N D F E D_{0}\right)$ is a dummy variable equals 1 if $D F E_{0}$ is positive (negative) and 0 otherwise. $P C E D_{0}\left(N C E D_{0}\right)$ is a dummy variable that equals 1 if $C E_{0}$ is positive (negative) and 0 otherwise, $t$-statistics are reported in parentheses, * significant at $5 \%, * *$ significant at $1 \%$.

Table 7: Simultaneous regression model (linear and nonlinear) for cumulative abnormal return and future asset-scaled earnings changes

Model 2: $\left(R O A_{t}-R O A_{t-1}\right)=\alpha+\beta_{1} C A R_{0}+\beta_{2} R O A_{t-1}+\varepsilon_{t}$

Model 3: $\left(R O A_{t}-R O A_{t-1}\right)=\alpha+\beta_{1 D R}\left(D R_{0} \times C A R_{0}\right)+\beta_{1 N D R}\left(N D R_{0} \times C A R_{0}\right)+\beta_{2} R O A_{t-1}+\beta_{3} C E_{0}+\varepsilon_{t}$

Model 4: $\left(R O A_{t}-R O A_{t-1}\right)=\alpha+\beta_{1 D R}\left(D R_{0} \times C A R_{0}\right)+\beta_{1 N D R}\left(N D R_{0} \times C A R_{0}\right)+$

$\left(\chi_{1}+\chi_{2} N D F E D_{0}+\chi_{3} N D F E D_{0} \times D F E_{0}+\chi_{4} P D F E D_{0}\right) \times D F E_{0}$

$+\left(\kappa_{1}+\kappa_{2} N C E D_{0}+\kappa_{3} N C E D_{0} \times C E_{0}+\kappa_{4} P C E D_{0} \times C E_{0}\right) \times C E_{0}+\varepsilon_{t}$

\begin{tabular}{ccccccc}
\hline & \multicolumn{2}{c}{ Model 2 } & \multicolumn{2}{c}{ Model 3 } & \multicolumn{2}{c}{ Model 4 } \\
\hline \multirow{2}{*}{$t=1$} & $t=2$ & $t=1$ & $t=2$ & $t=1$ & $t=2$ \\
\hline & 0.031 & 0.022 & 0.056 & 0.017 & -0.006 & -0.011 \\
& $\left(10.30^{* *}\right)$ & $\left(5.18^{* *}\right)$ & $\left(5.57^{* *}\right)$ & $\left(3.84^{* *}\right)$ & $\left(-2.51^{*}\right)$ & $\left(-4.18^{* *}\right)$ \\
$\beta_{1}$ & 0.010 & -0.007 & & & & \\
& $\left(5.83^{* *}\right)$ & $(-1.58)$ & & & & \\
$\beta_{2}$ & -0.002 & -0.091 & -0.064 & -0.096 & & \\
& $(-0.12)$ & $(-1.28)$ & $(-1.12)$ & $(-1.52)$ & & -0.052 \\
$\beta_{1 D R}$ & & & 0.077 & 0.092 & 0.007 & $(-0.82)$ \\
$\beta_{1 N D R}$ & & $\left(3.53^{* *}\right)$ & $(1.15)$ & $\left(3.17^{* *}\right)$ & -0.028 \\
\hline
\end{tabular}




\begin{tabular}{|c|c|c|c|c|c|c|}
\hline & & & (1.31) & $(0.49)$ & $(0.76)$ & $(-1.07)$ \\
\hline \multirow{2}{*}{$\beta_{3}$} & & & 0.240 & 0.014 & & \\
\hline & & & $(0.50)$ & $(0.24)$ & & \\
\hline \multirow{2}{*}{$\chi_{1}$} & & & & & -0.652 & -0.483 \\
\hline & & & & & $\left(-3.88^{* *}\right)$ & $(-1.81)$ \\
\hline \multirow{2}{*}{$\chi_{2}$} & & & & & 0.209 & 0.200 \\
\hline & & & & & (1.51) & $(0.96)$ \\
\hline \multirow{2}{*}{$\chi^{3}$} & & & & & 4.329 & 1.171 \\
\hline & & & & & $\left(3.19^{*}\right)$ & (1.35) \\
\hline \multirow{2}{*}{$\chi_{4}$} & & & & & -2.184 & -0.174 \\
\hline & & & & & $(-1.29)$ & $(-0.06)$ \\
\hline \multirow{2}{*}{$\kappa_{1}$} & & & & & 0.428 & 0.440 \\
\hline & & & & & $\left(2.97^{*}\right)$ & $\left(4.55^{* *}\right)$ \\
\hline \multirow{2}{*}{$\kappa_{2}$} & & & & & -0.158 & -0.444 \\
\hline & & & & & $(-0.95)$ & $\left(-3.52^{* *}\right)$ \\
\hline \multirow{2}{*}{$\kappa_{3}$} & & & & & -0.014 & -2.204 \\
\hline & & & & & $(-0.02)$ & $\left(-2.17^{*}\right)$ \\
\hline \multirow{2}{*}{$\kappa_{4}$} & & & & & 1.184 & -0.602 \\
\hline & & & & & (0.97) & $(-1.10)$ \\
\hline$R^{2}$ & 0.086 & 0.072 & 0.104 & 0.107 & 0.132 & 0.105 \\
\hline$N$ & 448 & 448 & 448 & 448 & 448 & 448 \\
\hline
\end{tabular}

$E_{t}$ denotes the income before interest and tax excluding the extraordinary items at the end of year $t$ after dividends release year, $R O A_{t}$ is the earnings on asset at the end of year the beginning of dividends release year, $C A R_{0}$ is the cumulative abnormal return for days $(-5,5), D R$ and NDR are dummy variables that equals 1 for $D R(N D R)$ and 0 otherwise. $C E_{0}=\left(R O A_{0}-R O A_{-1}\right) . D F E_{0}=R O A_{0}-E\left[R O A_{0}\right]$. E[ROA $A_{0}$ is the fitted value from the cross-sectional regression of $R O A_{0}$ on the logarithm of total assets in year -1 , the logarithm of the market-to-book ratio of equity in year -1 , and $R O A_{-1}$. PDFED $\left(N D F E D_{0}\right)$ is a dummy variable equals 1 if $D F E_{0}$ is positive (negative) and 0 otherwise. $P C E D_{0}\left(N C E D_{0}\right)$ is a dummy variable that equals 1 if $C E_{0}$ is positive (negative) and 0 otherwise, $t$-statistics are reported in parentheses, * significant at $5 \%, * *$ significant at $1 \%$.

Figure 1: Mean abnormal return for dividends release and no dividend release samples 


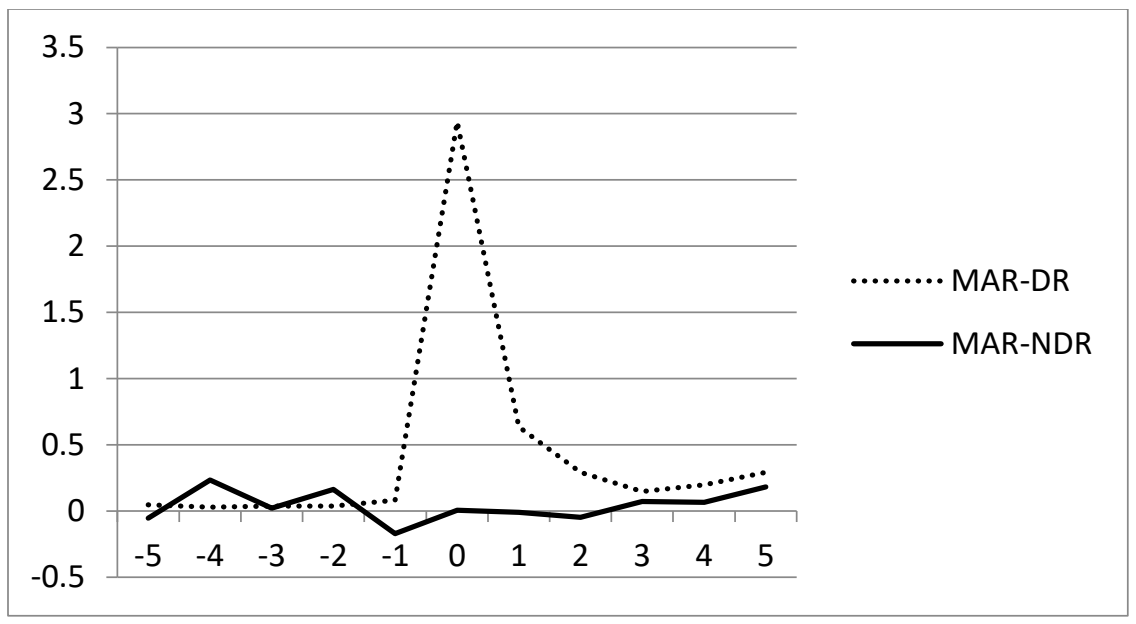

Figure 2: Cumulative abnormal return for dividends release and no dividend release samples

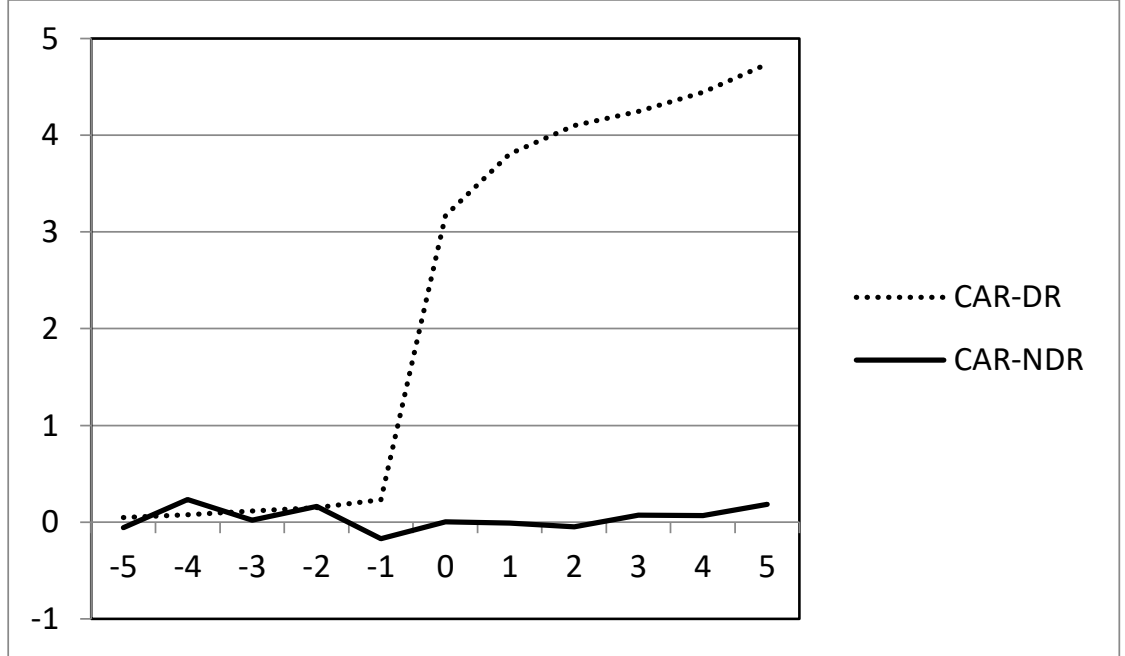

